Copyright (C 2021 University of Bucharest Printed in Romania. All rights reserved

ISSN print: $1224-5984$

ISSN online: $2248-3942$
Rom Biotechnol Lett. 2021; 26(3): 2640-2649 doi: $10.25083 / \mathrm{rbl} / 26.3 / 2640.2649$

Received for publication, October, 1, 2020

Accepted, January, 8, 2021

Original paper

\title{
Analysis of the agricultural labor force and its impact on agricultural products obtained in the South-Muntenia region
}

\author{
FLORINA RUXANDRA TEODORESCU ${ }^{1}$, LIVIU MĂRCUȚ $\breve{A}^{1 *}$, CĂTĂLINA- \\ NICOLETA COMAN ${ }^{1}$, VALENTINA CONSTANȚA TUDOR ${ }^{1}$
}

${ }^{1}$ University of Agronomic Sciences and Veterinary Medicine Bucharest, 59 Marasti, Romania

\begin{abstract}
This paper aims to highlight the impact that the labor force in the agricultural sector has on the production obtained from the main crops in the South-Muntenia development region, Romania, in the period 2014-2018. Following the study of theoretical aspects in the fields mentioned above and combining these studies with the interpretation and analysis of statistical data, an analysis will be established to establish the level at which the agricultural labor force in the South-Muntenia region impacts the productions of five important crops. Romanian agricultural sector, respectively: wheat, corn, sunflower, rapeseed and soybeans. In the South-Muntenia region, made up of Argeș, Călărași, Dâmbovița, Giurgiu, Ialomița, Prahova and Teleorman counties, the percentage of people working in the agricultural sector in 2018 was $27.8 \%$ of the total population of this region.
\end{abstract}

Keywords South Muntenia region, labor force, population, area, production.

To cite this article: TEODORESCU FR, MĂRCUȚĂ L, COMAN CN, TUDOR VC. Analysis of the agricultural labor force and its impact on agricultural products obtained in the South-Muntenia region. Rom Biotechnol Lett. 2021; 26(3): 2640-2649. DOI: $10.25083 / \mathrm{rbl} / 26.3 / 2640-2649$

*Corresponding author: MĂRCUȚĂ LIVIU, University of Agronomic Sciences and Veterinary Medicine Bucharest, 59 Marasti, 011464, Phone: +40 (21) 31825 64, District 1, Bucharest, Romania E-mail: marcuta.liviu@ managusamv.ro 


\section{Introduction}

Labor is an extremely important factor in any production process, especially in the agricultural process that could not be achieved without human intervention, the extremely close link between agriculture itself as a science and the labor force deriving from the fact that one one of the functions that agriculture has in Romania's economic development is that of labor provider (DONA [13]; ONCIOIU [21]).

By definition, the labor force represents the active population of an administrative unit. The labor force relative to the active population, including in these terms employees with individual employment or self-employment and the unemployed (EC.EUROPA.EU [14]) and taking into account the importance of the agricultural sector in generating labor, being together with industry, the most important labor-generating sectors in Romania (MARCUTA \& al [19]), the analysis of how the labor force in agriculture influences the productions of five important crops in our country is extremely necessary to be able to predict what may happen in the future close or distant with the level of crop production that propels us to the stage of agriculture in the European Union (COFAS \& al [7]). Thus, knowing the labor force involved in agricultural processes, we can determine how the type of people who are involved in the agricultural process influences by number, age or level of training the production of wheat, corn, sunflower, rapeseed and soybeans, the five crops that in 2018 ranked us among the European performers, our country being on the fourth place in wheat production, on the first place in the case of corn and sunflower productions, on the two place in the production of soybeans and fifth in rapeseed production (LEGISLATIE.JUST.RO [15]).

\section{Materials and Methods}

In accordance with the theoretical information accumulated on the topics mentioned in this paper and combining this information with statistical data procured from the National Institute of Statistics (ins.ro), by Eurostat (ec.europa.eu/eurostat), the body that deals with statistics at the level of the European Commission and by the OCDE (OECD [22]) a study based on the interpretation, research and analysis of data in order to understand how the workforce in agriculture influences the productions of five important crops at national level, within the South Muntenia development region.

The data will be interpreted by calculating arithmetic means, trends or data distribution.

The arithmetic mean is the operation by which all the observed individual values of a variable are added and divided by their number, resulting in a value that could be obtained if each individual value marked the variable equally (ASE.RO [10]; IOSIFESCU \& al [18]).

The trend, known as the general trend that a series of values knows, signifies the direction of development of the values within the series, being represented by a movement, the evolution of the series values in a predetermined period of time (DEXONLINE [12]).

Data distribution refers to how the elements of a data string are distributed within the string (DEXONLINE [11]).

\section{Results and Discussion}

According to Law 151/1998 on regional development, amended by Law 315/2004 (with subsequent amendments and completions) in compliance with EC Regulation no. 1059/2003 (AVENA [25]), in order to apply the regional development policy as they result according to art. 2, para. (1) of Law 315/2004, on the field of economic and social cohesion in accordance with the objectives of the European Union and the general objectives and priorities on the development of Romania (LEGISLATIE.JUST.RO [4]), in order to ensure the continuous economic and social development of the country, have Romania's development regions were represented, represented by certain geographical areas, meant to reduce the social and economic discrepancies between our country and the rest of states belonging to the E.U. (LEGISLATIE.JUST.RO [3]).

According to Chapter II of Law 315/2004 (with subsequent completions and amendments), 8 development regions were established on the Romanian territory that do not have legal personality and do not represent administrative-territorial units (LEGISLATIE.JUST.RO [5]). Operating under Law 315/2004 with subsequent amendments and completions, regional development policies are developed, implemented and evaluated within the development regions, and at the same time according to EUROSTAT, through the European regulations issued for NUTS 2, the second level of territorial classification existing in within the European Union, specific statistical data will be collected at the level of development regions. Comprising the territories of the counties in Romania as well as that of the Municipality of Bucharest, these territorial administrative units of which the development regions are composed can associate to pursue interests with a common objective (LEGISLATIE.JUST.RO [6]).

The above-mentioned annex of the law names and specifies the composition of development regions in Romania, as follows (LEGISLATIE.JUST.RO [2]): North-East Development region - made up of Bacău, Botoșani, Iași, Neamț, Suceava, and Vaslui counties, South-East Development region. East- made up of Brăila, Buzău, Constanța, Galați, Vrancea and Tulcea counties, South-Muntenia Development region- made up of Argeș, Călărași, Dâmbovița, Giurgiu, Ialomița, Prahova and Teleorman counties, South-West Oltenita Development region from the counties of Dolj, Gorj, Mehedinți, Olt and Vâlcea, the West Development region - made up of the counties of Arad, Caraș-Severin, Hunedoara and Timiș, the North-West Development region - made up of the counties of Bihor, Bistriţa-Năsăud, Cluj, Sălaj, Satu Mare 
and Maramureș, the Central Development Region - made up of Alba, Brașov, Covasna, Harghita, Mureș and Sibiu counties, the Bucharest-Ilfov Development region, made up of Bucharest and Ilfov County.

Located in the South-Eastern part of Romania, in the historical region of Muntenia known in the past as Wallachia or Wallachia, the development region of South Muntenia, a land of contrasts with a fascinating history, has a stepped relief, reaching up to $2,544 \mathrm{~m}$ above sea level, the maximum altitude in Romania found on the lofty peaks of the Carpathian Mountains, at average altitudes of $64 \mathrm{~m}$ above sea level in the Romanian Plain, south of which flows the Danube (INFOREGIO [26]; ADR [27]), which gives this region a considerable advantage, namely the direct connection with the eight riparian countries, with access to the port of Constanta, through the Danube-Black Sea canal (FONDURI - STRUCTURALE.RO [1]). Comprising 7 counties, the largest number of counties among the 8 development regions, in terms of population, South-Muntenia region, ranks second nationally out of 8 , representing $15 \%$ of the total population of Romania, on the territory of this region living in 2018
2,929,832 people. In terms of area, in 2014 the SouthMuntenia region had the third with access to the port largest area in the country after the North-East and South-East region, with an area equal to 3,445,299 ha, representing approximately $14.5 \%$ of the total area of the country.

If in the introduction we noted that the labor force represents the totality of people who meet all the requirements for employment, we conclude that the labor force in agriculture sums up the people who meet all the requirements for employment and work in agriculture.

In the 1990s, Romania was called the "Granary of Europe" in the European community, because some of the largest quantities of wheat that fed the entire continent were exported from Romania [9]. Today, analyzing the statistical data presented in Table 1, in Romania still works in 2018 of $21 \%$ of the total population employed in agriculture. Although in the last two years the number of people employed in agriculture has increased, this increase is insufficient to exceed the number of people working in agriculture in the first year of the reference period, from 2014.

Table 1. Percentage of the population employed in the agricultural sector from the total population employed in the South-Muntenia region

\begin{tabular}{lccccc}
\hline \multicolumn{1}{c}{ Region/County } & $\mathbf{2 0 1 4}(\boldsymbol{\%})$ & $\mathbf{2 0 1 5}(\boldsymbol{\%})$ & $\mathbf{2 0 1 6}(\boldsymbol{\%})$ & $\mathbf{2 0 1 7}(\boldsymbol{\%})$ & $\mathbf{2 0 1 8}(\boldsymbol{\%})$ \\
\hline TOTAL Romania & 27.33 & 24.02 & 20.76 & 20.82 & 20.93 \\
SOUTH-MUNTENIA & 35.27 & 31.48 & 27.71 & 27.76 & 27.80 \\
Region/ & & & & & 19.82 \\
Arges & 26.87 & 23.41 & 19.95 & 19.78 & 41.49 \\
Calarasi & 48.23 & 44.55 & 41.01 & 41.39 & 27.00 \\
Dambovita & 34.98 & 30.93 & 27.12 & 27.19 & 41.69 \\
Giurgiu & 50.00 & 46.10 & 41.69 & 41.36 & 37.76 \\
Ialomita & 44.47 & 41.19 & 36.98 & 37.34 & 15.84 \\
Prahova & 20.98 & 18.32 & 15.85 & 15.92 & 45.85 \\
Teleorman & 53.90 & 49.50 & 45.14 & 45.62 & \\
\hline
\end{tabular}

Source: NIS - TEMPO-Online [16], data access and processing-03.2020;

In the analyzed region, in 2018 the number of people employed in agriculture is quite high, because in the counties that make up this region agriculture is still a basic occupation (COMAN \& al [8]). Therefore, the counties with a flatter relief, where agriculture is more easily practiced, have a higher number of people working in agriculture than the counties with hilly and/or mountainous relief, respectively Argeș, Prahova counties. Between the two groups of counties is Dâmbovița County. The leading counties are as follows: Teleorman, Giurgiu, Călărași and Ialomiţa.

Although only $20 \%$ of employed people work in agriculture, Romania ranks first in the European Union in 2018, where the average number of people employed in agriculture is $4 \%$, according to Eurostat (REVISTA FERMIERUL [23]). However, this result should not reassure us, because according to specialists in the field, the Romanian agricultural workforce is aging and modestly professionally prepared, so the modernization of the agricultural process brings problems to agricultural producers, in the sense that there are not enough specialists in the field who can work at the same pace as the modernizations brought, so they are not properly prepared to produce at full capacity (WIKIPEDIA [24]; TINDECHE $\&$ al [28]). Therefore, the first position occupied at E.U. In terms of the number of people employed in agriculture, we should not be happy since the population employed in agriculture we have not only does not cover the need for labor, here the migration of people who used to work in agriculture to other States of the E.U. which gave them a more decent living or the satisfaction of some of the agricultural workers who have so far got used to and satisfied with the low income brought by social assistance 
(FINANCIALINTELLIGENCE [16]; MARCUTA \& al [20]).

Calculating the percentage of agricultural area of the total area, of the arable area of the total area and then of the arable one, we can observe that at the level of the region, a little over $70 \%$ of the total area is the agricultural area, the arable area occupying more than half of the total area. South-Muntenia. Of the agricultural area, about $81 \%$ is arable land, the rest being occupied by pastures, hayfields, vineyards and vineyards, as well as orchards and nurseries, non-agricultural land, forests and other forest vegetation, land occupied by water and ponds or buildings, or with roads and railways, degraded and unproductive land or other surfaces (Table 2). Within the region, Călărași County has the largest arable area both in the total area of the county and in the agricultural area. Teleorman County has the largest agricultural area of the total land fund. On the territory of Argeș county, the smallest agricultural and arable areas of the total area of the county are registered.

Table 2. Percentage of agricultural and arable of the South-Muntenia region in 2014

\begin{tabular}{lccc}
\hline \multicolumn{1}{c}{ Region/County } & $\begin{array}{c}\text { Agricultural area / } \\
\text { total area }(\boldsymbol{\%})\end{array}$ & $\begin{array}{c}\text { Arable area / total area } \\
(\boldsymbol{\%})\end{array}$ & $\begin{array}{c}\text { Arable area/ agricultural } \\
\text { area }(\boldsymbol{\%})\end{array}$ \\
\hline SOUTH-MUNTENIA/ & 70.63 & 57.15 & 80.91 \\
Arges & 50.15 & 25.48 & 50.80 \\
Calarasi & 83.69 & 80.68 & 96.41 \\
Dambovita & 61.15 & 43.25 & 70.73 \\
Giurgiu & 78.16 & 73.44 & 93.96 \\
Ialomita & 84.10 & 79.08 & 94.03 \\
Prahova & 57.14 & 30.38 & 53.16 \\
Teleorman & 86.00 & 78.56 & 91.35 \\
\hline
\end{tabular}

Source: NIS - TEMPO-Online [17], data access and processing - 03.2020;

Figure 1 shows the graph of the distribution of the three types of areas in the development regions of Romania in 2014, as follows: the lower circle shows the distribution of data on the total area, in the middle circle the agricultural area and in the circle outside the arable surface.

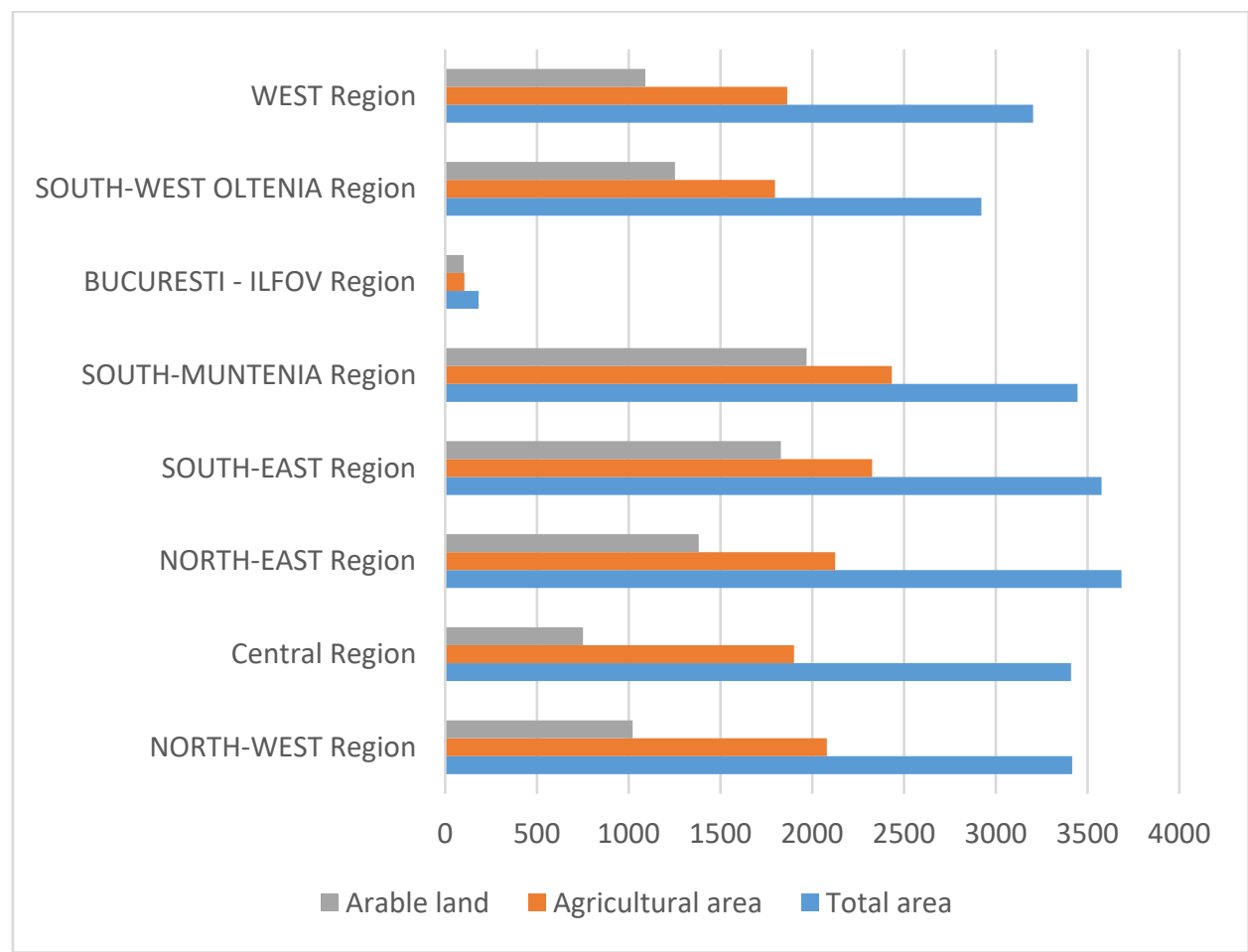

Figure 1. Distribution of total area, agricultural area and arable land in the development regions of Romania in 2014. (Source: Data processing on the NIS- TEMPO-Online [17]). 
At national level, the analyzed region is the third region as an area of the total land fund with a percentage of $14.5 \%$ although, as we mentioned in the paper, it is the region composed of the largest number of counties.
Not surprisingly, being largely covered by the plain, this region has both the largest agricultural area and the largest arable area in the country, with $16.63 \%$, respectively $20.96 \%$ (Figure 2).

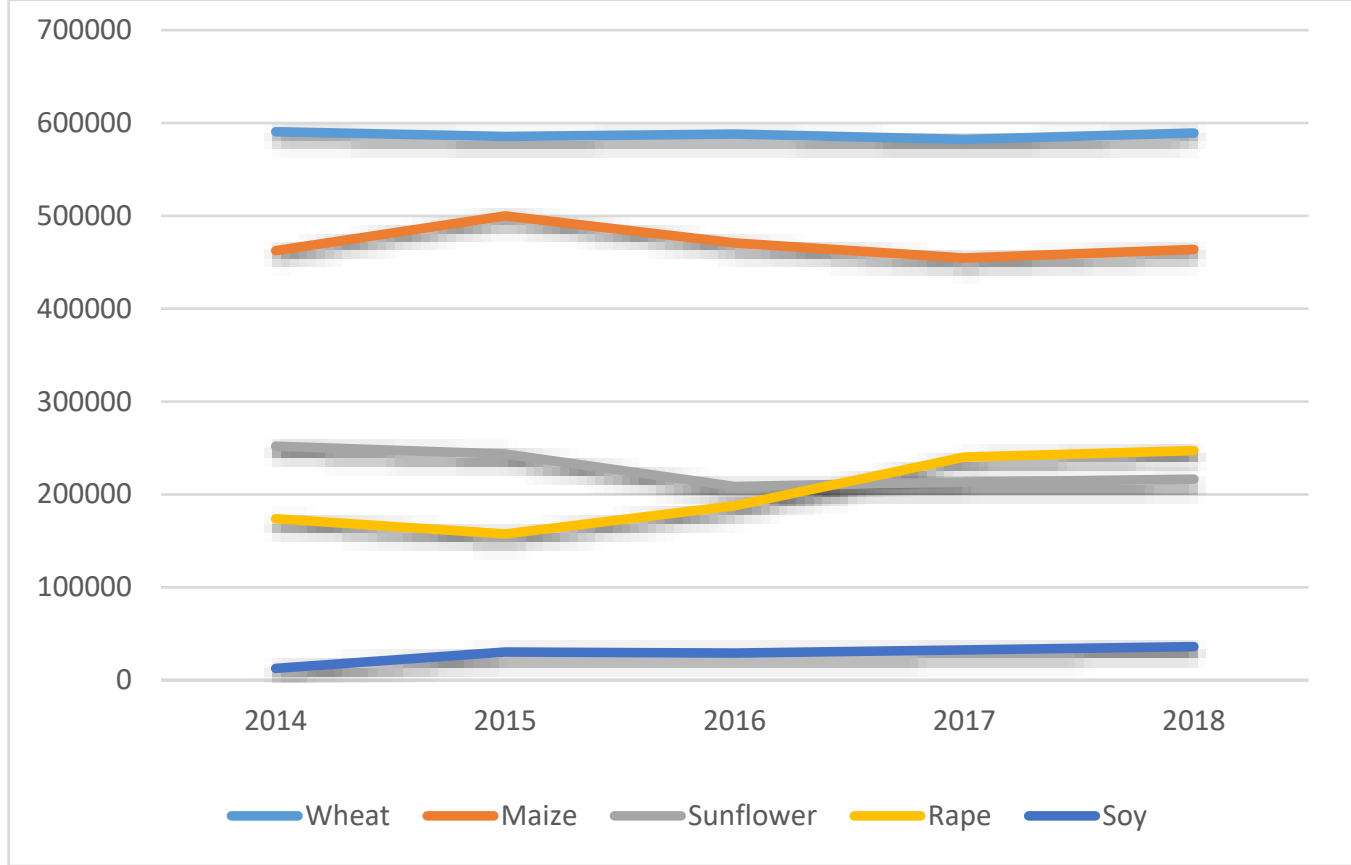

Figure 2. The trend of cultivated areas with the main crops in the South-Muntenia region during 2014-2018 (Source: Data processing on the National Institute of Statistics - TEMPO-Online [17]).

Regarding the area cultivated with the main crops, namely wheat, corn, sunflower, rapeseed and soybean, during the years 2014-2018, in accordance with the trend shown in Figure 3, we can see that the area cultivated with wheat has an almost linear in the 5 years, the largest change of this area being over 1.16\% from 2017 to 2018; for the total period analyzed, this area decreased by less than $0.5 \%$. The difference of hectares between the area cultivated with corn in 2014 and that of 2018 is only 1,301 hectares, although from 2014 to 2015 it increased by $8 \%$, the decreases in the following years led to an insignificant increase at the end of 2018 for this surface (Table 3).

Regarding the trend of the sunflower area, we can compare it with a balance whose plates are uneven, this similarity coming from the fact that in 2014-2016, this area decreased by $17.7 \%$, while since 2016 in 2017 began to grow, increasing to almost $4 \%$ by 2018 , but insufficient growth to cover the decline in the first reference years, so that the area cultivated with sunflower in the region decreased by just over 14\% during the years 2014-2018 (Figure 2).

Regarding the evolution of the area cultivated with rapeseed, we observe a continuous increase starting with the second year of the reference period, increasing by the end of the period by $42 \%$. The area cultivated with soybeans increased from 2014 to 20182.5 times.

Regarding the areas of the five crops in the component counties of the South-Muntenia region according to the data in Table 3 in 2018 the average wheat area was 84,162 ha/county, the largest area cultivated with wheat being in Teleorman county, with 163,385 hectares, and the county with the smallest area cultivated with wheat was Dâmbovița county with 35,302 hectares. The county average for the area cultivated with corn, in the same year is equal to $66,263 \mathrm{ha} /$ county, on the territory of Călărași county being the largest area of corn, respectively 102,302 hectares, and within Giurgiu county being the smallest, 44,404 hectares (Table 3). 
Table 3. County average of the areas of the main crops in the South-Muntenia region, in the period 2014-2018

\begin{tabular}{lrrrrr}
\hline Culture & $\mathbf{2 0 1 4}(\boldsymbol{\%})$ & $\mathbf{2 0 1 5}(\boldsymbol{\%})$ & $\mathbf{2 0 1 6}(\boldsymbol{\%})$ & $\mathbf{2 0 1 7}(\boldsymbol{\%})$ & $\mathbf{2 0 1 8}(\boldsymbol{\%})$ \\
\hline Wheat & 84369.00 & 83633.43 & 84005.57 & 83194.43 & 84162.14 \\
Maize & 66077.29 & 71414.71 & 67252.86 & 64948.57 & 66263.14 \\
Sunflower & 35999.00 & 34783.71 & 29798.14 & 30476.14 & 30925.71 \\
Rape & 24838.71 & 22492.43 & 26842.57 & 34326.14 & 35310.00 \\
Soy & 1819.43 & 4333.29 & 4167.00 & 4662.71 & 5162.14 \\
\hline
\end{tabular}

Source: NIS - TEMPO-Online [17], data access and processing - 03.2020;

The average sunflower area per county is equal to 30,925 hectares, in Teleorman county being the largest area, 63,568 ha, and the smallest in Argeș county, 12,691 hectares. Also in Argeș County is the smallest area cultivated with rapeseed, 5,856 hectares, while the largest area cultivated with rapeseed is in Călărași County, 68,126 hectares, the county average for this area being equal to 35,310 hectares. The largest soybean area is also found in Călărași County and is equal to 18,751 hectares, over half of the total soybean area in the region, while the smallest soybean area is found in Dâmbovița County, 84 hectares, the average at the level of the region being 5,162 hectares.

In 2018, on the territory of the South-Muntenia region was registered the largest area of wheat in a percentage of almost $28 \%$ of the total area cultivated with wheat in Romania, the average per region being equal to 264,519 hectares, also the largest area cultivated with corn, $19 \%$ of the total in the country, the average per region being equal to 304,980 hectares and the largest area cultivated with rapeseed, in percentage of $39 \%$, in the conditions of a national average of 79,084 hectares. For cultivated areas with sunflower and soybeans, the development region of South Muntenia is on the second position with $21.5 \%$ of the total in the country in the case of the area cultivated with sunflower, with a smaller area by almost $10 \%$ than the region in the first position, ie the South-East region; and by $21.33 \%$ of the national total in the case of the area cultivated with soybeans, by $1.5 \%$ less than the region with the largest area cultivated with soybeans, respectively the region of the West. The averages per region in terms of sunflower and soybean cultivation are equal to 128,303 hectares, respectively 38,601 hectares (Table 4, Figure 3).

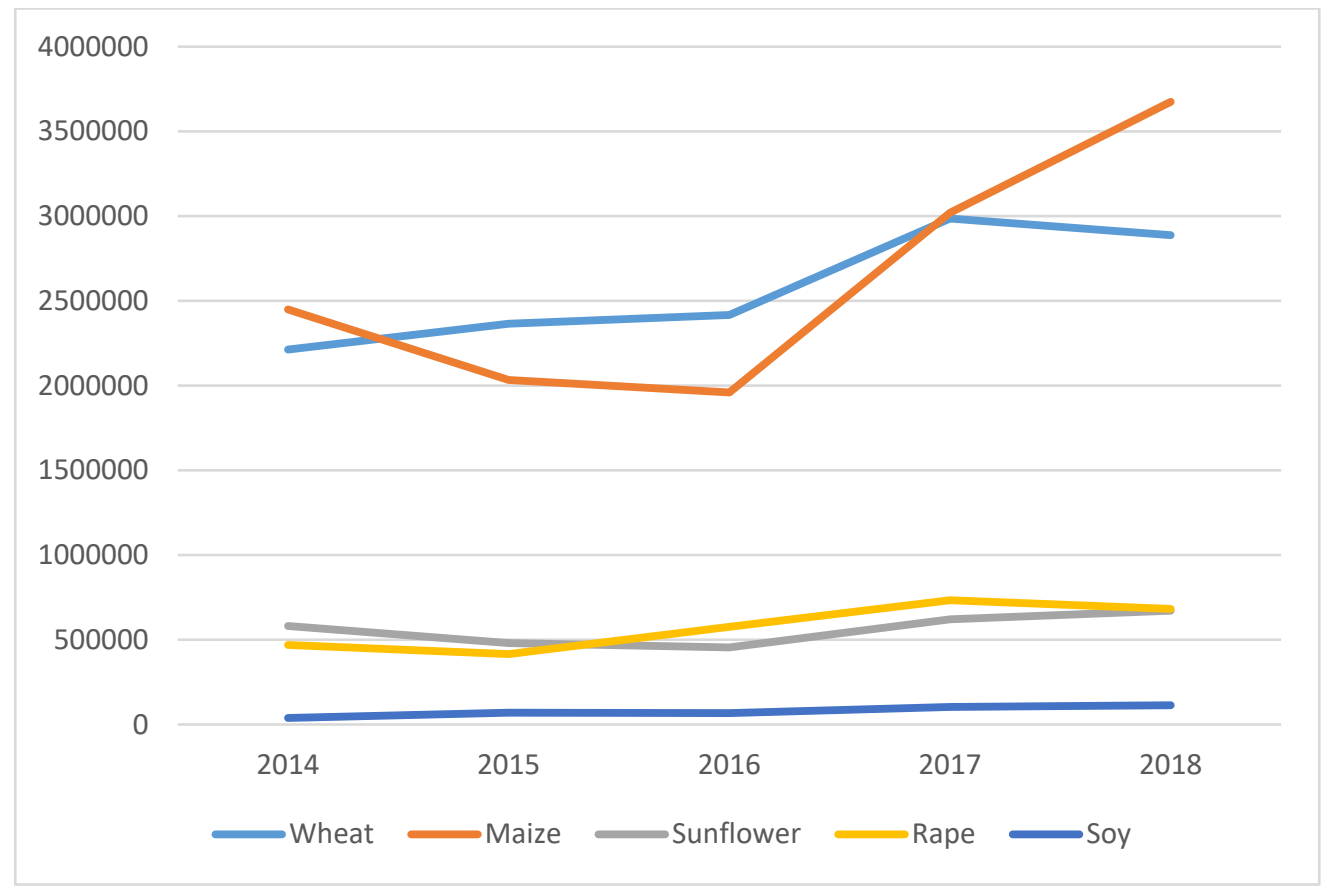

Figure 3. The trend of the productions of the main crops in the South-Muntenia region in the period 2014-2018

(Source: Data processing on the NIS - TEMPO-Online [17]). 
Table 4. County average of the productions of the main crops from the South-Muntenia region, in the period 2014-2018

\begin{tabular}{lrrrrr}
\hline Culture & $\mathbf{2 0 1 4}(\boldsymbol{\%})$ & $\mathbf{2 0 1 5}(\boldsymbol{\%})$ & $\mathbf{2 0 1 6}(\boldsymbol{\%})$ & $\mathbf{2 0 1 7}(\boldsymbol{\%})$ & $\mathbf{2 0 1 8}(\boldsymbol{\%})$ \\
\hline Wheat & 316055.43 & 337828.00 & 345253.29 & 426505.86 & 412502.86 \\
Maize & 349892.86 & 290419.00 & 279909.57 & 431423.29 & 524909.29 \\
Sunflower & 83051.00 & 68675.57 & 64976.14 & 88642.14 & 95960.29 \\
Rape & 67041.57 & 59351.57 & 82323.00 & 104764.86 & 104764.86 \\
Soy & 5513.43 & 9979.86 & 9659.71 & 14794.86 & 16220.00 \\
\hline
\end{tabular}

Source: NIS - TEMPO-Online [17], data access and processing - 03.2020;

With regard to the production of the five main crops, wheat, maize, sunflower, rapeseed and soybean, interpreting the data contained in Table 4, as well as the trends of these crops represented in Figure 3, in the SouthMuntenia development region, as the following phenomena follow. Throughout the analyzed period, 2014-2018, all five productions show an upward trend. In wheat production, the increase in production was constant, except for the decrease from 2017 to 2018 by almost $4 \%$. Considering that the relief of the southern and central part of the region is mainly represented by the plain, it is substantiated that in the counties of Călărași and Teleorman the highest productions are registered in terms of the five crops, and the smallest are in the northern counties, where in addition to the plain, the relief is also made up of hills and mountains (AVENA [25]), such as Argeș and Dâmbovița. Therefore, with an average per county equal in 2018 with 412,502 tons, in Teleorman county the highest production was registered being equal to 781,749 tons. The county with the lowest production was Dâmbovița in the same year, with 117,118 tons. Overall, wheat production increased by $30.5 \%$ over the reference period. The county average of corn production was equal in 2018 with 524,909 tons, in Călărași county obtaining the highest production, equal to 924,439 tons in that year, and in Prahova county the lowest production 325,727 tons. Over the period analyzed, maize production throughout the region increased by $50 \%$.

Sunflower production has a county average of 95,960 in 2018, the highest sunflower production being obtained in Teleorman County, 228,300 tons, and the lowest in Dâmbovița County, 28,882 tons. Of the five productions analyzed, sunflower production increased the least, by almost $16 \%$. Increasing over the period taken into account by over $45 \%$, rapeseed production has an average in the county in 2018 equal to 97,477 tons, the highest production being made in Calarasi county which was equal to 205,987 tons, and the smallest production was made in Argeș County and was equal to 9,147 tons.

Knowing the largest increase during the analyzed period, by almost $200 \%$, soybean production records in
2018 an average per county equal to 16,220 tons, in Calarasi county being obtained 54,919 tons, the highest soybean production in 2018, representing almost half of the total soybean production in the region. In Dâmbovița County, in the same year, only 121 tons were obtained, thus placing this county on the last place in terms of soybean production in the region.

At national level, over the years taken into account, the highest productions of the five crops analyzed were obtained in the South-East and South-Muntenia regions, regions that have as a predominant form of relief the plain. Therefore, in 2018, in the South-Muntenia region were obtained the highest productions of wheat $(28.47 \%)$, corn $(19.69 \%)$ and rapeseed $(42.36 \%)$. At the sunflower and soybean production, the South-Muntenia region ranks second at national level, after the South-East region, within the analyzed region obtaining $21.93 \%$ of the national total of sunflower production (more than $10 \%$ less than the South-East region) and $24.39 \%$ of national soybean production (1.09\% less than the South-East region).

Analyzing the data included in Table 5, as well as the graphs in Figure 4, we notice that both at the level of the entire region and at the level of each county, we observe the development of two main trends, extremely important in the analysis performed. First of all, we are talking about the main direction of development of the population employed in agriculture which during the analyzed period developed an upward trend, the number of persons employed in agriculture within the South-Muntenia region decreasing from 2014 to 2018 by $23.86 \%$, the county level of this decline being just over $23 \%$. Secondly, the evolutionary trend that the productions of the five crops analyzed show, namely the almost constant increases that the productions of the five cultures know in all the five years chosen as the reference period that led as less in the case of rapeseed production. from Dâmbovița county, sunflower productions from Giurgiu and Ialomița counties and wheat production from Prahova, the rest of the productions of the five crops, both in the region and in the counties, where important increases have taken place. Soybean increases were recorded in Dâmbovița and Prahova counties. 
Table 5. The ratio of the productions of the five crops to the population employed in agriculture in the South-Muntenia region in the years 2014-2018

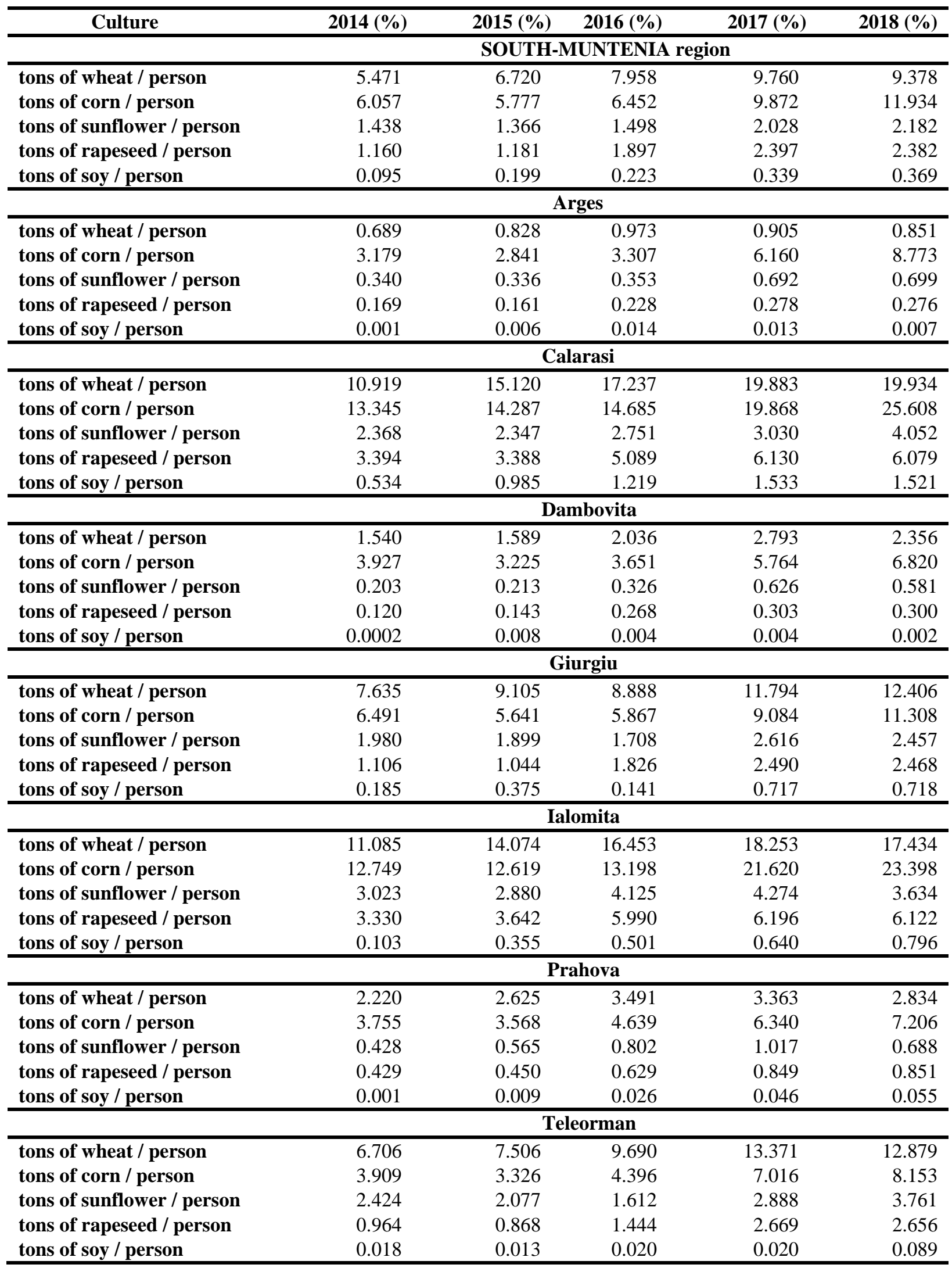

Source: NIS - TEMPO-Online [17], data access and processing - 03.2020 


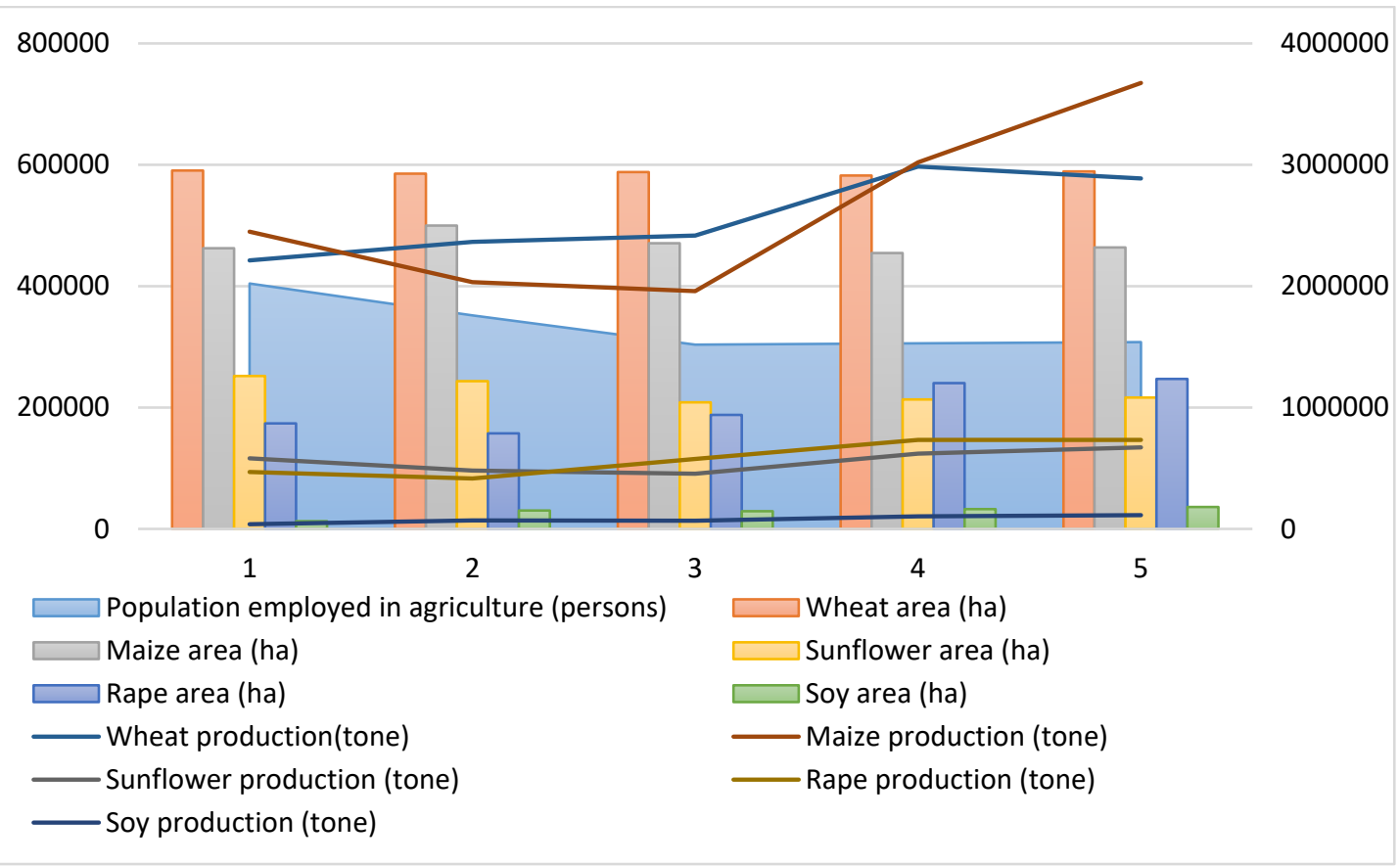

Figure 4. Evolution of areas, productions of main crops and population employed in agriculture in the South-Muntenia region during 2014-2018 (Source: Data processing on the NIS - TEMPO-Online [17]).

Representing the results of the agricultural process, the production of a crop depends on factors that can not be influenced by human will, such as climatic conditions. Things are pretty simple on this aspect, any person, whether they are employed in agriculture or not aware of the effects that weather conditions have on the resulting yields. If it does not rain enough during the germination period, the plants do not develop properly or at all, if when they are in the growth stage, the heat wave is present, the plants will burn and dry out, or the pests that endure these extreme conditions will produce more a lot of damage. The biggest problem of people who are engaged in agriculture in Romania, so in the South-Muntenia development region is certainly the lack of water. The insufficiency of irrigation systems puts its imprint on the productions obtained, especially in the South-Muntenia region which for more than five years, those taken in the analysis, face the lack of precipitation during key periods for plant development, being located in the area the warmest in the country. Therefore, it is not inexplicable that although the number of people employed in agriculture decreased during the analyzed period, the production of wheat, maize, sunflower, rapeseed and soybean crops increased significantly in the five years.

In addition to climate, another element that influences the level of production of the five crops is the cultivated area. The way in which this element influences the production can be best observed in the case of soybean production, because following the data presented in Table 5, as well as the trends presented in Figure 4 we will see that both in the region as a whole and in each county In part, soybean production increased as the area under cultivation increased. However, although the area devoted to a certain crop clearly influences in the end the fruits of the agricultural process, in the South-Muntenia region, during the years 2014-2018, the figures obtained in the case of wheat cultivation make us think twice when the area influences the production, because although the area cultivated with wheat in the South-Muntenia development region decreased by 1,448 hectares from 2014 to 2018 , the wheat production increased by 675,132 tons in the same period.

The totally opposite trends registered in the period 2014-2018 by the population employed in agriculture and the productions of wheat, corn, sunflower, rapeseed and soybean crops in the South-Muntenia region, led to the increase of the number of tons belonging to a persons employed in agriculture, so that if in 2014 a person employed in agriculture was allocated in proportion to the number of tons obtained and the population employed in agriculture 5.4 tons of wheat, 6 corn, 1.4 sunflower, 1 rapeseed and 0.09 tonnes of soybeans, in 2018 these values increased by $71 \%$ for wheat, $97 \%$ for maize, $51 \%$ for sunflower, $105 \%$ for rape and $286 \%$ for production obtained by soybeans.

\section{Conclusion}

The analysis of the main indicators regarding employment and cultivated areas in the analyzed region resulted in the following conclusions:

- The population employed in agriculture decreased, the causes being both the aging population and the fact that innovative technologies, high-performance equipment require less and less labor. 
- Romania is still ranked first among the countries in the European Union in terms of labor in agriculture, with a percentage of $20 \%$ of total employment nationally.

- The the analyzed region, due to the climatic particularities, of the agricultural potential is on the first two places at country level in terms of the productions obtained for the five analyzed crops.

- Traditional wheat and maize crops do not show large variations in the analyzed period in terms of cultivated areas, unlike sunflower, rapeseed and soybeans which recorded significant increases $(43 \%$ for sunflower and $250 \%$ for soybeans)

- Productions increased for all five crops, depending on the particularities of the soils in the region, these increases being $30 \%$ for wheat, $50 \%$ for corn, $15.5 \%$ for sunflower, $45 \%$ for rape and $200 \%$ for soy.

- The empirical study shows that the labor force in agriculture has a direct influence on the level of production recorded, these being influenced by weather conditions, the existence or non-existence of irrigation systems, applied technologies, the degree of endowment and investments made in Romania's agriculture, but also the level of subsidies which in turn influence the structure of crops.

\section{Acknowledgements}

We thank the referees for all the data provided for this paper. The publication of this article was possible thanks to the sectoral project ADER 23.1.1: "Technical-economic basis of production costs and estimates regarding the prices of capitalization of the main plant and animal products, obtained in conventional system and in organic farming" Subcontract no: 23.1.1./2-03.10.2019 contracted with the Ministry of Agriculture and Rural Development.

\section{Conflict of Interest}

The authors have no conflict of interest to declare.

\section{References}

1. Analiza socio-economică a regiunii Sud-Muntenia, Februarie 2013, www.fonduri-structurale.ro/Document_ Files//Stiri/00012672/utsf3_analizasocecpdr20142020dra ft3revizuit110213_am_encrypted.pdf

2. Anexa din Legea 315/2004, legislație. just.ro/Public/ DetaliiDocument/53040.

3. Art. 2, alin. (1) din Legea 315/2004, legislatie. just.ro/ Public/DetaliiDocument/53040.

4. Art. 2, alin. (2) din Legea 315/2004, legislatie. Just.ro/ Public/DetaliiDocument/53040.

5. Art. 5, alin. (1), (2) din Legea 315/2004, legislatie.just.ro/ Public/DetaliiDocument/5304.

6. Art. 6, alin. (1), (2), (3) din Legea 315/2004, legislatie. just.ro/Public/DetaliiDocument/5304.

7. COFAS ELENA, TOMA ELENA, URSU ANA, DOBRE CARINA. The analysis of the potential for biomass exploitation in the context of bio-economy. Case study: wheat and maize crops, Rom Biotechnol Lett. 2020; Vol. 25(1), doi: 10.25083/rbl/25.1/1208.1215), pp. 1208-1215.

8. COMAN CATALINA, TUDOR VALENTINA CONSTANTA. Demographic analysis of South Muntenia region, Scientific Papers Series Management, Economic Engineering in Agriculture and Rural Development, Vol. 19, Issue 2, 2019 PRINT ISSN 2284-7995, E-ISSN 2285-3952.

9. CONDEI R., POPESCU A., BĂLAN A., TUDOR V. Aspects of employment in agriculture in the main development regions of Romania, Scientific Papers. Series "Management, Economic Engineering in Agriculture and rural development”, Vol. 15 ISSUE 2, PRINT ISSN 2284-7995, 67-74.

10. Curs statistică-Unitatea de învățare nr. 5, Analiza statistică a distributiiilor de frecvențe. Indicatorii tendintei central, Academia de studii economice, www.ase.ro/upcpr/ profesori/1825/UI5- Seii\%20de\%20distr.ind.tend.centr

11. dexonline.ro/definitie/distribuție

12. dexonline.ro/definitie/trend

13. DONA I. Curs Economie Rurală, www.managusamv.ro/ images/pdf /ECONOMIERURALA.pdf

14. ec.europa.eu/eurostat/statistics-explained/index.php/ Glossary:Labour_force

15. fermierinromania.ro/romania-printre-performele-europeila-sase-culturi-vegetale-anul-trecut-incepe-competitiapentru-2019

16. financialintelligence.ro/lipsa-muncitorilor-calificati-insectorul-agricol-a-condus-la-o-crestere-spectaculoasa-acastigurilor/

17. Institutul Naţional de Statistică - TEMPO-Online - statistici. insse.ro: 8077/tempo-online/\#/pages/tables/insse-table

18. IOSIFESCU M., MOINEAGU C., TREBICI V., URSIANU E. Mică enciclopedie de statistică, Editura Științifică și Enciclopedică, București.

19. MARCUTA ALINA, MARCUTA LIVIU, TINDECHE CRISTINA, ANGELESCU CARMEN, NICULAE IOANA. The influence of economic crisis on the labour in the European Union's member states, Scientific Papers Series Management, Economic Engineering in Agriculture and Rural Development, Vol. 14, Issue 1, 2014 PRINT, ISSN 2284-7995, E-ISSN 2285-3952.

20. MARCUTA LIVIU, MARCUTA ALINA, ANGELESCU CARMEN. Effects of the Economic Crisis on the Standard of Living in Romania, Procedia Economics and Finance 6 ( 2013 ) 89-95.

21. ONCIOIU IONICA. Increasing agricultural productivity and sustainable development, Romanian Biotechnological Letters, Vol. 19, No 3, 2014.

22. Organizația pentru Cooperare și Dezvoltare Economică (OECD) - data.oecd.org/emp/labour-force.htm

23. revistafermierului.ro/romania-agricola/item/4014-un-sfertdin-populatia-tarii-ocupata-in-agricultura-suntem-pe-locul-iin-ue.html

24. ro.wikipedia.org/wiki/Regiunea_de_dezvoltare_SudMuntenia

25. SC AVENSA CONSULTING SRL. Studiu privind stadiul actual de dezvoltare al infrastructurii în regiunea SudMuntenia și perspective de dezvoltare, Decembrie 2012

26. Strategia națională pentru dezvoltare regională 2014-2020, 2003, București-www.inforegio.ro/images/Documente_ de_programare/Strategia_Nationala_Dezvoltare_Regiona la_-_iulie_2013.pdf

27. www.adrmuntenia.ro/turism/static/11

28. TINDECHE CRISTIANA, MARCUTA ALINA, MARCUTA LIVIU. Importance of the agricultural sector as a branch of the national economy, Scientific Papers Series Management, Economic Engineering in Agriculture and Rural Development, Vol. 14, Issue 4, 2014 PRINT, ISSN 2284-7995, E-ISSN 2285-3952. 